\title{
Understanding the Growth Hormone Therapy Adherence Paradigm: A Systematic Review
}

\author{
Benjamin G. Fisher ${ }^{a}$ Carlo L. Acerini ${ }^{a}$ b \\ ${ }^{a}$ Department of Paediatrics, University of Cambridge, and ${ }^{\mathrm{b}}$ The Weston Centre, Institute of Metabolic Science, \\ Cambridge University Hospitals Foundation NHS Trust, Cambridge, UK
}

\author{
Key Words \\ Growth hormone therapy · Serum insulin-like growth \\ factor I. Patient compliance
}

\begin{abstract}
Introduction: Growth hormone (GH) therapy is used to treat a variety of growth disorders in childhood/adolescence. Its efficacy is thought to be dependent on patients' adherence to their treatment regimen. Methods: PubMed was searched using the keywords 'growth hormone', 'child'[Mesh], 'adolescent'[Mesh], and 'patient compliance'[Mesh]. Results: Most studies of adherence to paediatric GH therapy have used either issued/encashed GH prescriptions or questionnaires. Estimates of prevalence of non-adherence vary from $5-82 \%$, depending on the methods and definitions used. Different studies have variously demonstrated an association (or lack thereof) between adherence and age, socioeconomic status, treatment duration, injection device used and injection-giver. A number of interventions have been proposed to improve adherence, including offering a choice of injection device, but none are supported by trials. Poor adherence is associated with reduced height velocity and likely increased economic costs; evidence for other effects is circumstantial. Conclusion: Adherence to paediatric $\mathrm{GH}$ therapy is suboptimal, which may partially explain why the mean final height attained is below that of the general population. Analysis of the causes of non-adherence is com-
\end{abstract}

\section{KARGER}

E-Mail karger@karger.com

www.karger.com/hrp plicated by conflicting evidence from different studies. Multifactorial interventions are most likely to be successful in improving adherence. We make recommendations for further research.

Copyright $\odot 2013$ S. Karger AG, Basel

\section{Introduction}

Growth hormone (GH) has been used for over 50 years for the treatment of growth disorders [1], most recently in the form of recombinant human growth hormone (rhGH, somatropin) [2]. The objectives of GH therapy during childhood and adolescence are to normalise height velocity as quickly as possible and attain a final adult height within the normal range, whilst minimising risks and cost [3]. Licensed paediatric indications in Europe include poor growth due to GH deficiency, Turner syndrome, Prader-Willi syndrome, chronic renal insufficiency and short stature homeobox-containing gene deficiency as well as children born small for gestational age [3]; there is good evidence that GH therapy improves the growth of these patients and, in children with PraderWilli syndrome, also their body composition $[4,5]$. Additional paediatric indications in other countries include achondroplasia, Noonan syndrome and idiopathic short stature [2]. Following completion of linear growth, which occurs around the time of transition to adult services [6], 
GH therapy may be continued at adult doses in patients with severe GH deficiency, on the basis that GH therapy improves body composition, bone mineral density, cardiac function, lipid profile and quality of life [6].

The success of GH therapy, as in other chronic conditions, is thought to be dependent on the patient's ability to maximally adhere to their treatment regimen. Conceptualisations of adherence vary widely [7], but a commonly used definition is 'the extent to which a person's behaviour, with regard to taking medication, following a diet and/or executing lifestyle changes, corresponds with agreed recommendations from a health-care provider' [8]. Some authors differentiate adherence from compliance, i.e. 'the extent to which the patient's behaviour... coincides with clinical prescription' [9] and concordance, i.e. 'participation of the patient in the decision-making process' [10], but the three terms are generally used interchangeably within research and clinical practice [7]. Similarly, definitions of non-adherence (or non-compliance) also vary: some authors specify fixed cut-offs, such as an adherence rate of less than 80 or $95 \%$ [11], whereas others consider it to be 'when the failure to comply is sufficient to interfere appreciably with achieving the therapeutic goal' [12].

Drug adherence in paediatrics is unique because of the involvement of a third party, i.e. the parent/guardian, and because the child is often unaware of the purpose of the medication and is reluctant to take it [13]. Whilst adherence rates in both adult and paediatric patients vary widely [14], adherence is generally best in adulthood and worst in adolescence, with intermediate rates in childhood [14, 15]. Optimising adherence in paediatric patients is important, as non-adherence may lead to additional diagnostic tests or hospitalisation, unnecessary changes of the drug dose or treatment course, increased health care costs and poorer health outcomes $[8,16,17]$.

This article adopts an evidence-based approach to assess various aspects of adherence to paediatric GH therapy: methods of measuring adherence, prevalence of nonadherence, factors affecting adherence, interventions to improve adherence and the costs of non-adherence.

\section{Methods}

A search of the medical literature was undertaken in PubMed. The following keywords were used: 'growth hormone', 'human growth hormone'[Mesh], 'child'[Mesh], 'child, preschool'[Mesh], 'adolescent'[Mesh] and 'patient compliance'[Mesh]. The reference lists of identified articles were also searched for papers on the topic.

\section{Results}

\section{Methods of Measuring Adherence to GH Therapy}

Adherence to a given treatment regimen can be assessed using a wide variety of methods, each with their own advantages and disadvantages [11]. There is no goldstandard method, and a combination of measures is recommended to maximise accuracy $[11,18]$. A review of all possible methods is beyond the scope of this article. However, the majority of studies examining adherence to paediatric GH therapy have used one of the following two indirect methods:

(1) Issued, renewed or encashed rhGH prescriptions: this method has been used in several studies of GH therapy adherence [19-21] and has advantages in that it is relatively objective, unobtrusive and inexpensive, and that data are easy to obtain $[11,18]$. It also shows good concordance with other adherence measures [22]. Its disadvantages are that it provides only a gross measure of adherence (it does not measure delays in the timing of doses or inappropriate use with other medications) and it does not take into account failure to encash prescriptions or indeed administer rhGH $[11,21]$.

(2) A questionnaire completed by patient and/or parents: such self-report measures have moderate-to-strong concordance with measures using prescription records [23], with the advantage that they are simple, inexpensive and practical [11]. Their main disadvantage is poor sensitivity for non-adherence (often less than $50 \%$ [18]), which may be due to difficulty recalling details of medication administration, desire to avoid confrontation, fear of disappointing clinicians or a combination of reasons [24]. Another disadvantage is time dependence, as patients have the best recall for adherence in the preceding 24-hour period and a consequent susceptibility to the 'white-coat adherence' effect whereby they improve their medication-taking behaviour in the 5 days before an appointment [11].

There is some evidence that biochemical measurements could also be used to directly assess adherence to $\mathrm{GH}$ therapy:

(3) Urinary GH levels: Phillip et al. [25] and Skinner et al. [26] demonstrated that 12-hour overnight urinary GH levels are significantly higher in patients receiving rhGH than in those who are off treatment, with a significant fall in urinary levels after just 2 missed doses. However, to our knowledge no studies of GH therapy adherence have used this method, presumably because of difficulties with feasibility [18]. 
(4) Serum insulin-like growth factor I (IGF-I) levels: GH induces hepatic and local tissue production of IGF-I, and serum total IGF-I levels have long been used to guide rhGH dose adjustment in adults with GH deficiency [27]. Consensus statements on paediatric GH therapy have advocated IGF-I monitoring for over a decade, to avoid overtreatment, assess adherence and, more recently, guide rhGH dosing [28-30]; however, a 2009 study showed that many clinicians continue not to routinely monitor IGF-I levels during GH therapy [31]. There is now good evidence that titrating the rhGH dose to achieve IGF-I targets at the upper limit of normal significantly improves growth responses compared with standard weight-based dosing [32]. However, to our knowledge no studies have validated the other role of serum IGF-I measurement as a biomarker for adherence, despite its common use in routine clinical practice [30] and even as the gold standard in a validation study of a self-report adherence questionnaire [33]. A strong dose-response effect of rhGH on serum IGF-I levels in children has been demonstrated in at least 1 observational study [34] and in 3 randomised controlled trials $[32,35,36]$, although 2 other observational studies have failed to find a correlation in children with GH deficiency [31, 37]. Furthermore, all of these studies assessed variation in the daily dose of rhGH, rather than the frequency of injection. One adult crossover trial has indicated that the same weekly dose of GH given as three injections per week reduces serum IGF-I levels compared to daily administration [38], but 2 others have shown no difference in IGF-I levels $[39,40]$. The above heterogeneity in results is likely due to a combination of factors, including lack of IGF-I assay standardisation, variable adherence and the wide diversity in IGF-I responsiveness to GH stimulation [31]: IGF-I response varies with age, height, BMI, fat mass and underlying growth disorder [34, 41]. Cohen et al. [32] demonstrated a more than 15 -fold variation in the $\mathrm{GH}$ doses required to maintain IGF-I levels at +2 SDS $(20-346 \mu \mathrm{g} / \mathrm{kg} /$ day). For this reason, it is difficult to determine whether an individual low IGF-I level represents poor adherence, low sensitivity to rhGH and/or other factors.

\section{Prevalence of Non-Adherence to GH Therapy}

Various studies have attempted to assess the prevalence of non-adherence to paediatric GH therapy. Estimates vary from 5 to $82 \%$, depending on the methods and definitions used (table 1).

Understanding GH Therapy Adherence

\section{Factors Affecting Adherence to GH Therapy}

Barriers to GH therapy adherence in paediatric patients may include medication issues (e.g. apparent ineffectiveness, inadequate supply and side effects), scheduling issues (social convenience) and cognitive/emotional issues (e.g. forgetfulness, preoccupation, lack of understanding of condition or instructions, lack of symptoms, fear of needles, poor tolerability and inadequate family support). Additional barriers in adolescence may include: denial, peer pressure and reluctance to seek medical advice $[16,20,42,43]$.

Factors specifically associated with poor adherence to GH therapy in observational studies are listed in table 2; notably, several factors have been associated with poor adherence in some studies but not in others.

\section{Interventions to Improve Adherence to GH Therapy}

It is evident from the above that there is a need for effective interventions to improve the adherence to $\mathrm{GH}$ therapy in paediatric patients. To our knowledge, there is only 1 published randomised controlled trial addressing this issue, which found no difference in adherence between patients who had been allocated a needle-free injection device and those allocated a multi-dose injection pen [44]. Based on injection-device acceptability studies, observational studies of GH therapy adherence and studies of other paediatric diseases, a number of interventions have been proposed to improve adherence to GH therapy (table 3).

Patient choice of injection delivery device is of particular relevance to clinical practice in those health-care settings where more than one type of product is potentially on offer to patients and families. GH therapy is usually administered as a daily subcutaneous injection of rhGH [3] and to personalise therapy, the pharmaceutical industry has developed a number of different injection devices that vary in size, shape, injection product, dose range and increments, storage, requirement for reconstitution, method of injection (manual, automatic or needle-free) and associated support services [45]. As of 2012, seven manufacturers have marketing authorisations for rhGH [5], and in some countries, a choice of up to twelve different devices is offered at paediatric endocrinology centres. Historically, injection devices were chosen on behalf of the patient by medical and nursing staff [46], but in recent years many endocrinology centres have moved away from this practice and offer some form of patient choice upon initiation of GH therapy, with larger centres generally offering a wider range of devices [47]. Indeed, in countries such as the UK, national clinical guidelines 
Table 1. Prevalence of non-adherence to GH therapy in paediatric patients

\begin{tabular}{|c|c|c|c|c|}
\hline Study & Patient population & Method of assessing adherence & Definition of non-adherence & $\begin{array}{l}\text { Propor- } \\
\text { tion of } \\
\text { patients, \% }\end{array}$ \\
\hline $\begin{array}{l}\text { Smith } \\
\text { et al. [63] }\end{array}$ & $\begin{array}{l}188 \text { patients attending the Middlesex } \\
\text { Hospital Endocrinology Clinic }\end{array}$ & $\begin{array}{l}\text { questionnaire completed by person } \\
\text { responsible for administering rhGH }\end{array}$ & $\begin{array}{l}\text { injections missed: } \\
\text { >5 since last clinic visit } \\
\text { injections missed: } \\
>10 \text { since last clinic visit }\end{array}$ & 51 \\
\hline $\begin{array}{l}\text { Stanhope } \\
\text { et al. [64] }\end{array}$ & $\begin{array}{l}107 \text { patients attending Great Ormond } \\
\text { Street Hospital Endocrinology Clinic } \\
\text { and associated peripatetic clinics }\end{array}$ & $\begin{array}{l}\text { interview in the presence of a } \\
\text { growth research nurse }\end{array}$ & injections missed: $\geq 3$ per month & 10 \\
\hline $\begin{array}{l}\text { Smith } \\
\text { et al. [49] }\end{array}$ & $\begin{array}{l}177 \text { patients attending the Middlesex } \\
\text { Hospital Endocrinology Clinic }\end{array}$ & $\begin{array}{l}\text { questionnaire completed by person } \\
\text { responsible for administering rhGH }\end{array}$ & $\begin{array}{l}\text { failure to comply with all aspects of } \\
\text { treatment }\end{array}$ & $16-42$ \\
\hline Rees [65] & $\begin{array}{l}29 \text { patients with renal disease in a } \\
\text { multicentre UK study }\end{array}$ & $\begin{array}{l}\text { questionnaire completed by patient } \\
\text { and/or parents }\end{array}$ & $\begin{array}{l}\text { injections missed: } \geq 1 \text { per month } \\
\text { injections missed: } \geq 6 \text { per month }\end{array}$ & $\begin{array}{r}62 \\
7\end{array}$ \\
\hline $\begin{array}{l}\text { Oyarzabal } \\
\text { et al. [51] }\end{array}$ & $\begin{array}{l}473 \text { patients attending } 17 \text { paediatric } \\
\text { endocrinology clinics in Spain }\end{array}$ & $\begin{array}{l}\text { questionnaire administered by } \\
\text { nurse to patient and/or parents }\end{array}$ & $\begin{array}{l}\text { injections missed: } \geq 5 \% \text { since last } \\
\text { clinic visit }\end{array}$ & 6 \\
\hline $\begin{array}{l}\text { Postlethwaite } \\
\text { et al. [42] }\end{array}$ & $\begin{array}{l}17 \text { patients with renal disease from } 4 \\
\text { UK centres }\end{array}$ & interview of parents & $\begin{array}{l}\text { injections missed: }<1 \text { per week } \\
\text { injections missed: } \geq 1 \text { per week }\end{array}$ & $\begin{array}{c}35-82 \\
6-9\end{array}$ \\
\hline $\begin{array}{l}\text { Hunter } \\
\text { et al. [19] }\end{array}$ & Patients in Scotland & encashed rhGH prescriptions & injections missed: $>20 \%$ & 33 \\
\hline $\begin{array}{l}\text { Desrosiers } \\
\text { et al. [54] }\end{array}$ & 631 patients in North America & unknown & $\begin{array}{l}\text { injections missed: } \geq 3 \text { per month } \\
\text { injections missed: } \geq 15 \text { per month }\end{array}$ & $\begin{array}{r}15-24 \\
6-13\end{array}$ \\
\hline $\begin{array}{l}\text { Wickramasuriya } \\
\text { et al. [46] }\end{array}$ & $\begin{array}{l}50 \text { patients commencing GH through } \\
\text { the Children's Hospital in Birmingham }\end{array}$ & ampoule counts & $\begin{array}{l}\text { not specifically defined } \\
\text { median adherence rate was } 88-95 \%\end{array}$ & \\
\hline $\begin{array}{l}\text { Haverkamp } \\
\text { et al. [20] }\end{array}$ & 6,487 patients in Germany & renewed rhGH prescriptions & $\begin{array}{l}\text { failure to renew prescription during } \\
\text { first year of therapy }\end{array}$ & $5-10$ \\
\hline $\begin{array}{l}\text { Kapoor } \\
\text { et al. [21] }\end{array}$ & $\begin{array}{l}75 \text { patients attending Addenbrooke's } \\
\text { Hospital Endocrinology Clinic }\end{array}$ & issued rhGH prescriptions & $\begin{array}{l}\text { injections missed: }>1 \text { per week } \\
\text { injections missed: }>2 \text { per week }\end{array}$ & $\begin{array}{l}39 \\
23\end{array}$ \\
\hline $\begin{array}{l}\text { Rosenfeld and } \\
\text { Bakker [66] }\end{array}$ & 882 patients in California & $\begin{array}{l}\text { questionnaire completed by patient } \\
\text { and/or parents }\end{array}$ & $\begin{array}{l}\text { occasionally noncompliant or } \\
\text { noncompliant and sceptical }\end{array}$ & $64-77$ \\
\hline $\begin{array}{l}\text { Cutfield } \\
\text { et al. [53] }\end{array}$ & 175 patients in New Zealand & $\begin{array}{l}\text { number of rhGH vials required each } \\
\text { month } \\
\text { number of used rhGH vials returned }\end{array}$ & $\begin{array}{l}\text { injections missed: }>1 \text { per week } \\
\text { injections missed: }>1 \text { per week }\end{array}$ & $\begin{array}{l}34 \\
66\end{array}$ \\
\hline
\end{tabular}

state: 'The choice of product should be made on an individual basis after informed discussion between the responsible clinician and the patient and/or their carer about the advantages and disadvantages of the products available, taking into consideration therapeutic need and the likelihood of adherence to treatment' [3]. This is in accordance with more general national and international guidelines, which also stress the importance of taking into account patients' preferences when deciding on treatment and care $[8,48]$. There are no specific factors that predict which rhGH injection device a patient will choose $[3,46]$. However, GH therapy is expensive: five of the six licensed indications have an incremental cost-effectiveness ratio above the generally accepted cut-off of
GBP 30,000 per quality-adjusted life-years gained [5], and the marketed cost of rhGH can vary between manufacturers by up to $25 \%$ [47].

The effect on adherence of offering patients a choice of injection device has been examined in 3 observational studies. Smith et al. [49] compared 169 children who had started GH therapy before (group 1) or after (group 2) a change in policy offering patients 'a choice of GH preparation appropriate to their needs and a hospital-based clinical nurse specialist to train them in its use at home'. Adherence over a 3-month period was assessed using a self-completed questionnaire. In group 1,58\% of patients adhered to all aspects of their treatment, compared with $84 \%$ in group 2 ( $p<0.001)$. Similarly, Kapoor et al. [21] 
Table 2. Factors associated with poor adherence to GH therapy in paediatric patients

\begin{tabular}{|c|c|}
\hline Factors associated with poor adherence & Factors not associated with adherence \\
\hline 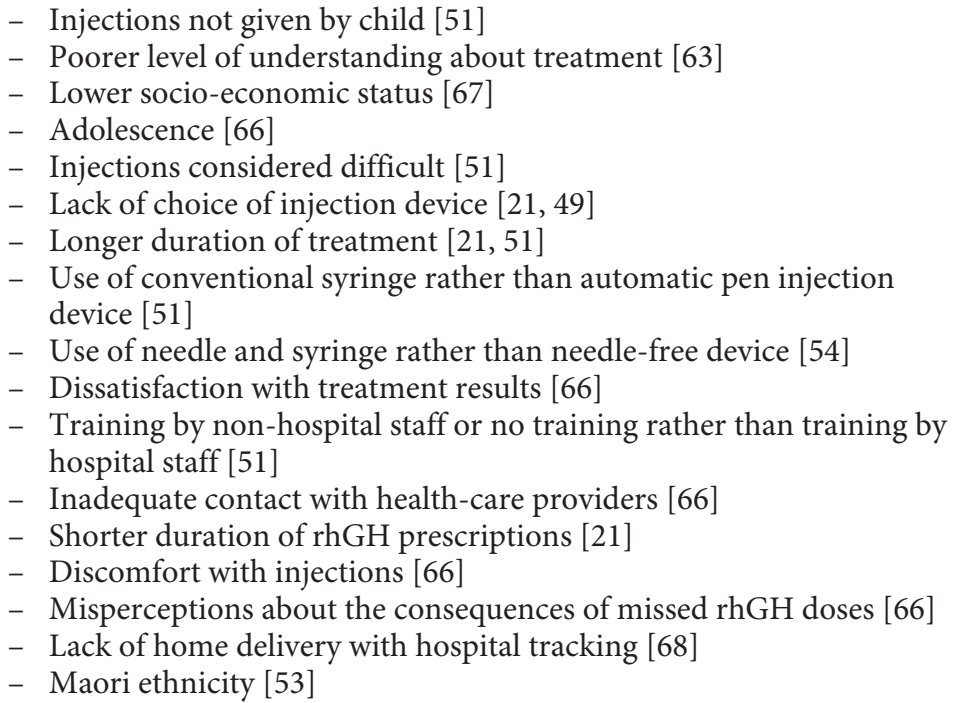 & $\begin{array}{l}\text { - Whether injections are given by parent or child [65] } \\
\text { - Level of understanding about treatment [65] } \\
\text { - Socioeconomic status [51] } \\
\text { - Age }[21,51,53] \\
\text { - Difficulty with injections [65] } \\
\text { - Whether offered choice of injection device [46] } \\
\text { - Duration of treatment [69] } \\
\text { - Type of injection device used }[21,46] \\
\text { - Concern regarding size or growth response [65] } \\
\text { - Age at commencement of treatment }[69] \\
\text { - Gender [51, 53,69] } \\
\text { - Underlying cause of short stature }[53,69] \\
\text { - Initial height standard deviation score }[21] \\
\text { - Clinical diagnosis [53] }\end{array}$ \\
\hline
\end{tabular}

compared 75 children who had started GH therapy before or after a change in policy offering patients a free choice of devices, this time estimating adherence from the number of rhGH prescriptions issued by GPs over a 12-month period. They too found a significant association between choice of injection device and greater adherence. An observational study of 165 children by Wickramasuriya et al. [46] reported that offering patients a choice of device had no significant effect on adherence, but this may be because adherence was already high (89\%) in the group who had not been given a choice [21].

It therefore seems likely that offering patients a choice of injection device upon initiation of GH therapy improves adherence. This is in agreement with studies in other paediatric populations showing a more general association between shared decision-making and adherence to therapy $[43,50]$. An additional consideration is that after starting GH therapy, patients may remain on rhGH for many years [3], during which time new or updated injection devices and associated support services may be introduced by pharmaceutical companies, and the patient's preference for injection devices and support may change. Indeed, adherence to GH therapy has been shown to decline with time in some studies [21, 51]. Preliminary results from a patient satisfaction questionnaire administered to patients on GH therapy suggest that patients and parents/guardians would value the opportunity to review their GH treatment package after a period
Table 3. Interventions that have been proposed to improve adherence to $\mathrm{GH}$ therapy in paediatric patients

- Giving patients a choice of injection devices [21, 49, 64]

- Use of automatic injection devices [70,71], injection pens [72] or a conceptual electronic device [73]

- Early patient and parent education and training [60, 74], at home [49] or with the involvement of dedicated clinical nurse specialist $[63,64]$

- An educational camp [75]

- Discussion of potential adverse effects [15]

- Mutual analysis of specific barriers to adherence by patient and clinician [20]

- Self-monitoring [10]

- Home delivery with hospital tracking [68]

- Longer duration of GH prescriptions, i.e. less frequent prescription collections and pharmacy visits [21]

- A token reinforcement system [11]

- Calendars and reminders [16]

- A 'written contract' defining specific responsibilities of each individual in the care of the patient [16]

- Involvement of immediate and extended family and social support $[11,16]$

- Support groups [10]

- Long-acting rhGH preparations [76]

of time [52]. It is therefore possible that offering patients a review of their $\mathrm{GH}$ treatment package several years after starting GH therapy will improve adherence. In their observational study, Wickramasuriya et al. [46] found no change in adherence in six children, initially offered a free 
choice of rhGH injection device, who subsequently elected to switch device; however, to our knowledge, there are no other studies to date which address this issue.

\section{Costs of Non-Adherence to GH Therapy}

Poor adherence to GH therapy is associated with reduced height velocity $[21,53,54]$, reflecting the correlation between injection frequency and growth response (i.e. height velocity and height standard deviation scores) [4]. Non-adherence may also feasibly lead to later cardiovascular and metabolic consequences in patients with $\mathrm{GH}$ deficiency [6], although we found no direct evidence for this. There are no studies assessing the effect of non-adherence on health-related quality of life (HRQOL), defined as 'a patient's perceptions of the impact of disease and treatment, functioning in a variety of dimensions including physical, mental, and social domains' [55]. However, a trial by Bannink et al. [56] demonstrated that GHpromoted height gain is associated with improvements in HRQOL in children born small for gestational age, and that after attainment of final height, GH therapy is associated with increased HRQOL in GH-deficient patients [57] probably as a result of its metabolic effects [58]. It is therefore feasible that non-adherence may adversely affect HRQOL in these patient groups.

There are also economic costs to non-adherence. $\mathrm{Di}$ rect costs include those due to additional diagnostic procedures, wasted medicines, increased rhGH dosage (with the concomitant increased risk of adverse effects), increased hospitalisation and/or additional drugs or other therapeutic interventions $[16,17,20,48]$. Studies of other chronic diseases have consistently found significant reductions in health care costs associated with interventions for improving adherence; for example, savings produced by optimal control of severe asthma have been estimated to be around $45 \%$ of the total medical costs [8]. Indirect costs include those due to the possible effects of non-adherence on the HRQOL, social roles and vocational productivity of the patient [8]. For example, Persico et al. [59] found that variation in teen height accounts for disparities in wages in later life of similar magnitude to those due to race and gender.

\section{Conclusion}

Adherence to paediatric GH therapy has been repeatedly demonstrated to be suboptimal, regardless of the assessment method used. Up to $82 \%$ of patients miss at least some rhGH doses. Poor adherence may be one of several reasons why the mean final height attained with GH therapy continues to be below that of the general population [60]. Analysis of the causes of non-adherence is complicated by conflicting evidence from different studies which variously demonstrate: an association or lack thereof between adherence and age, socioeconomic status, duration of treatment, level of understanding, injection giver, difficulty with injections, type of device used and choice of device. The reasons for these discrepancies are unclear, but may include differences in methodology, sample size and the population which is assessed.

Various interventions have been proposed to improve adherence to GH therapy, but none are supported by evidence from randomised controlled trials. It therefore falls to individual clinicians to decide which strategies to employ, based on the best available evidence. We feel strongly, for example, that offering patients a choice of rhGH injection device is important, and that attempts to restrict this choice for financial reasons may have detrimental effects on patient outcomes and potentially undermine longer-term health-economic benefits. The latter may be particularly relevant to those developed healthcare systems where patient choice is not an option because of the restrictions imposed by third-party payers (health insurers). It should also be borne in mind that 'no specific intervention can be recommended for all patients' [48], and that the most effective interventions for improving adherence (in adults, at least) are multi-factorial rather than single-focus $[8,61]$.

Based on the above, the following recommendations can be made:

(1) That future studies of adherence use a combination of measures of adherence to maximise accuracy.

(2) That research be undertaken to further assess:

a. The validity of serum IGF-I measurement in the assessment of adherence to GH therapy.

b. The factors associated with poor adherence, so that patients likely to struggle with adherence can be identified early on by clinicians and targeted appropriately.

c. The effects of poor adherence on final height, HRQOL and body composition.

d. The effects of offering patients a choice of rhGH injection device, both upon initiation and after a defined period of GH therapy. Important outcomes to be examined would include adherence, final height, HRQOL, body composition and the health-economic implications. It would also be useful to test the hypothesis that there may be an interaction between offering the patient a choice of devices and the patient's desire to be given such a choice [62]. 
e. The effects of other interventions on the above outcomes, such as training patients in rhGH injection at home, token reinforcement systems, 'written contracts', long-acting rhGH preparations and involvement of the extended family in GH therapy.

\section{Disclosure Statement}

C.L.A. has received honoraria (lecture fees, advisory board participation) or research funding support from the following manufacturers of rhGH in the last 5 years: Merck Serono Ltd., Novo Nordisk and Pfizer Inc.

\section{References}

1 Raben MS: Treatment of a pituitary dwarf with human growth hormone. J Clin Endocrinol Metab 1958;18:901-903.

2 Hintz RL: Growth hormone: uses and abuses. BMJ 2004;328:907-908.

3 National Institute for Health and Clinical Excellence: NICE technology appraisal guidance 188: human growth hormone (somatropin) for the treatment of growth failure in children 2010 (review). http://guidance.nice.org.uk/ TA188 (accessed October 27, 2012).

4 Takeda A, Cooper K, Bird A, Baxter L, Frampton GK, Gospodarevskaya E, et al: Recombinant human growth hormone for the treatment of growth disorders in children: a systematic review and economic evaluation. Health Technol Assess (Winch Eng) 2010;14: $1-209$.

5 Kirk J: Indications for growth hormone therapy in children. Arch Dis Child 2012;97:6368.

6 Radovick S, DiVall S: Approach to the growth hormone-deficient child during transition to adulthood. J Clin Endocrinol Metab 2007;92: 1195-1200.

7 Bissonnette JM: Adherence: a concept analysis. J Adv Nurs 2008;63:634-643.

8 World Health Organisation: Adherence to long-term therapies: evidence for action 2003. http://www.who.int/chp/knowledge/publications/adherence_report/en

9 Haynes RB, Taylor DW, Sackett DL: Compliance in Health Care. Baltimore, John Hopkins, 1979.

10 Hindmarsh PC, Brook CG: Compliance with growth hormone treatment - is it a problem? Horm Res 1999;51(suppl 3):104-108.

11 Osterberg L, Blaschke T: Adherence to medication. N Engl J Med 2005 Aug 4;353:487497.

12 O'Hanrahan M, O’Malley K: Compliance with drug treatment. BMJ 1981;283:298-300.

13 Matsui DM: Drug compliance in pediatrics: clinical and research issues. Pediatr Clin North Am 1997;44:1-14.

14 DiMatteo MR: Variations in patients' adherence to medical recommendations: a quantitative review of 50 years of research. Med Care 2004;42:200-209.

-15 Staples B, Bravender T: Drug compliance in adolescents: assessing and managing modifiable risk factors. Paediatr Drugs 2002;4:503513.
16 Tebbi CK: Treatment compliance in childhood and adolescence. Cancer 1993;71:34413449 .

-17 DiMatteo MR, Giordani PJ, Lepper HS, Croghan TW: Patient adherence and medical treatment outcomes: a meta-analysis. Med Care 2002;40:794-811.

18 Svarstad BL, Chewning BA, Sleath BL, Claesson C: The Brief Medication Questionnaire: a tool for screening patient adherence and barriers to adherence. Patient Educ Couns 1999; 37:113-124.

19 Hunter I, DeVries C, Morris A, MacDonald $T$, Greene S: Human growth hormone therapy: poor adherence equals poor growth. Arch Dis Child 2000;82(suppl 1):28.

20 Haverkamp F, Johansson L, Dumas H, Langham S, Tauber M, Veimo D, et al: Observations of nonadherence to recombinant human growth hormone therapy in clinical practice. Clin Ther 2008;30:307-316.

21 Kapoor RR, Burke SA, Sparrow SE, Hughes IA, Dunger DB, Ong KK, et al: Monitoring of concordance in growth hormone therapy. Arch Dis Child 2008;93:147-48.

22 Steiner JF, Prochazka A V: The assessment of refill compliance using pharmacy records: methods, validity, and applications. J Clin Epidemiol 1997;50:105-116.

23 Rickles NM, Svarstad BL: Relationships between multiple self-reported nonadherence measures and pharmacy records. Res Social Adm Pharm 2007;3:363-377.

24 Haynes RB, McDonald HP, Garg AX: Helping patients follow prescribed treatment: clinical applications. JAMA 2002;288:2880-2883.

25 Phillip M, Chalew SA, Stene MA, Kowarski AA: The value of urinary growth hormone determination for assessment of growth hormone deficiency and compliance with growth hormone therapy. Am J Dis Child 1993;147: 553-557.

26 Skinner AM, Clayton PE, Addison GM, Price DA: Nocturnal urinary growth hormone excretion in growth hormone-deficient children on and off growth hormone treatment. Horm Res 1995;44:147-151.

27 Lee KW, Cohen P: Individualizing growth hormone dosing in children. Horm Res 2001; 56(suppl 1):29-34.
28 Growth Hormone Research Society: Consensus guidelines for the diagnosis and treatment of growth hormone $(\mathrm{GH})$ deficiency in childhood and adolescence: summary statement of the GH Research Society. J Clin Endocrinol Metab 2000;85:3990-3993.

29 Cohen P, Rogol AD, Deal CL, Saenger P, Reiter EO, Ross JL, et al: Consensus statement on the diagnosis and treatment of children with idiopathic short stature: a summary of the Growth Hormone Research Society, the Lawson Wilkins Pediatric Endocrine Society, and the European Society for Paediatric Endocrinology Workshop. J Clin Endocrinol Metab 2008;93:4210-4217.

-30 Bang P, Ahmed SF, Argente J, Backeljauw P, Bettendorf $\mathrm{M}$, Bona $\mathrm{G}$, et al: Identification and management of poor response to growthpromoting therapy in children with short stature. Clin Endocrinol (Oxf) 2012;77:169181.

31 Cutfield WS, Lundgren F: Insulin-like growth factor I and growth responses during the first year of growth hormone treatment in KIGS patients with idiopathic growth hormone deficiency, acquired growth hormone deficiency, Turner syndrome and born small for gestational age. Horm Res 2009;71(suppl 1):3945.

32 Cohen P, Rogol AD, Howard CP, Bright GM, Kappelgaard A-M, Rosenfeld RG: Insulin growth factor-based dosing of growth hormone therapy in children: a randomized, controlled study. J Clin Endocrinol Metab 2007; 92:2480-2486.

- 33 Wilkins JP, Suman OE, Benjamin DA, Herndon DN: Comparison of self-reported and monitored compliance of daily injection of human growth hormone in burned children. Burns 2003;29:697-701.

34 Tillmann V, Patel L, Gill MS, Whatmore AJ, Price DA, Kibirige MS, et al: Monitoring serum insulin-like growth factor-I (IGF-I), IGF binding protein-3 (IGFBP-3), IGF-I/IGFBP-3 molar ratio and leptin during growth hormone treatment for disordered growth. Clin Endocrinol (Oxf) 2000;53:329-336.

35 Cohen P, Bright GM, Rogol AD, Kappelgaard A-M, Rosenfeld RG: Effects of dose and gender on the growth and growth factor response to $\mathrm{GH}$ in $\mathrm{GH}$-deficient children: implications for efficacy and safety. J Clin Endocrinol Metab 2002;87:90-98. 
-36 Bannink EMN, Van Doorn J, Stijnen T, Drop SLS, De Muinck Keizer-Schrama SMPF: Free dissociable insulin-like growth factor I (IGFI), total IGF-I and their binding proteins in girls with Turner syndrome during long-term growth hormone treatment. Clin Endocrinol (Oxf) 2006;65:310-319.

-37 Lanes R, Jakubowicz S: Is insulin-like growth factor-1 monitoring useful in assessing the response to growth hormone of growth hormone-deficient children? J Pediatr 2002;141: 606-610.

- 38 Johansson J-O, Wirén L, Oscarsson J, Bengtsson B-A, Johannsson G: Growth hormone (GH) replacement in $\mathrm{GH}$-deficient adults: a crossover trial comparing the effect on metabolic control, well-being and compliance of three injections per week versus daily injections. Growth Horm IGF Res 2003;13:306315.

-39 Amato G, Mazziotti G, Di Somma C, Lalli E, De Felice G, Conte M, et al: Recombinant growth hormone $(\mathrm{GH})$ therapy in $\mathrm{GH}$-deficient adults: a long-term controlled study on daily versus thrice weekly injections. J Clin Endocrinol Metab 2000;85:3720-3725.

-40 Giavoli C, Cappiello V, Porretti S, Ronchi CL, Orsi E, Beck-Peccoz P, et al: Growth hormone therapy in GH-deficient adults: continuous vs. alternate-days treatment. Horm Metab Res 2003;35:557-561.

41 Bouhours-Nouet N, Gatelais F, Boux de Casson F, Rouleau S, Coutant R: The insulin-like growth factor-I response to growth hormone is increased in prepubertal children with obesity and tall stature. J Clin Endocrinol Metab 2007;92:629-635.

-42 Postlethwaite RJ, Eminson DM, Reynolds JM, Wood AJ, Hollis S: Growth in renal failure: a longitudinal study of emotional and behavioural changes during trials of growth hormone treatment. Arch Dis Child 1998;78: 222-229.

43 Randolph C, Fraser B: Stressors and concerns in teen asthma. Curr Probl Pediatr 1999;29: 82-93.

- 44 Verrips GH, Hirasing RA, Fekkes M, Vogels T, Verloove-Vanhorick SP, Delemarre-Van de Waal HA: Psychological responses to the needle-free Medi-Jector or the multidose Disetronic injection pen in human growth hormone therapy. Acta Paediatr 1998;87: 154-158.

45 Ahmed SF, Smith WA, Blamires C: Facilitating and understanding the family's choice of injection device for growth hormone therapy by using conjoint analysis. Arch Dis Child 2008;93:110-114.

-46 Wickramasuriya BPN, Casey A, Akhtar S, Zia R, Ehtisham S, Barrett TG, et al: Factors determining patient choice of device for GH therapy. Horm Res 2006;65:18-22.
47 Langham S, Kirk J: National audit of patient choice in pediatric GH therapy. Horm Res 2011;75:101-105.

48 National Institute for Health and Clinical Excellence: NICE clinical guideline 76: medicines adherence: involving patients in decisions about prescribed medicines and supporting adherence 2009. http://guidance.nice. org.uk/CG76

49 Smith SL, Hindmarsh PC, Brook CG: Compliance with growth hormone treatment - are they getting it? Arch Dis Child 1995;73:277.

50 Kyngäs H, Rissanen M: Support as a crucial predictor of good compliance of adolescents with a chronic disease. J Clin Nurs 2001;10: 767-774.

51 Oyarzabal M, Aliaga M, Chueca M, Echarte G, Ulied A: Multicentre survey on compliance with growth hormone therapy: what can be improved? Acta Paediatr 1998;87:387-391.

52 Fisher BG, Gorman S, Reyes K, Sparrow S, Acerini CL: A survey of patient/carer opinions and preferences on choice of GH injection device. Endocr Abstr 2011;27:P9.

53 Cutfield WS, Derraik JGB, Gunn AJ, Reid K, Delany T, Robinson E, et al: Non-compliance with growth hormone treatment in children is common and impairs linear growth. PLoS One 2011;6:e16223.

54 Desrosiers P, O’Brien F, Blethen S: Patient outcomes in the GH Monitor: the effect of delivery device on compliance and growth. Pediatr Endocrinol Rev 2005;2(suppl 3):327331.

55 Varni JW, Seid M, Rode CA: The PedsQL: measurement model for the pediatric quality of life inventory. Med Care 1999;37:126-139.

56 Bannink EMN, Van Pareren YK, Theunissen NCM, Raat H, Mulder PGM, Hokken-Koelega ACS: Quality of life in adolescents born small for gestational age: does growth hormone make a difference? Horm Res 2005;64: 166-174.

7 Murray RD, Skillicorn CJ, Howell SJ, Lissett CA, Rahim A, Shalet SM: Dose titration and patient selection increases the efficacy of GH replacement in severely GH deficient adults. Clin Endocrinol (Oxf) 1999;50:749-757.

58 Brütt AL, Sandberg DE, Chaplin J, Wollmann $\mathrm{H}$, Noeker M, Kołtowska-Häggström M, et al: Assessment of health-related quality of life and patient satisfaction in children and adolescents with growth hormone deficiency or idiopathic short stature. Part 1. A critical evaluation of available tools. Horm Res 2009;72: 65-73.

59 Persico N, Postlewaite A, Silverman D: The effect of adolescent experience on labor market outcomes: the case of height. J Polit Econ 2004;112:1019-1053

60 Lustig RH: Optimizing growth hormone efficacy: an evidence-based analysis. Horm Res 2004;62(suppl 3):93-97.

-61 Roter DL, Hall JA, Merisca R, Nordstrom B, Cretin D, Svarstad B: Effectiveness of interventions to improve patient compliance: a meta-analysis. Med Care 1998;36:1138-1161.
62 Cvengros JA, Christensen AJ, Cunningham C, Hillis SL, Kaboli PJ: Patient preference for and reports of provider behavior: impact of symmetry on patient outcomes. Health Psychol 2009;28:660-667.

63 Smith SL, Hindmarsh PC, Brook CG: Compliance with growth hormone treatment - are they getting it? Arch Dis Child 1993;68:91-93.

64 Stanhope R, Moyle L, MacSwiney M: Patient knowledge and compliance with growth hormone treatment. Arch Dis Child 1993;68:525.

65 Rees L: Compliance with growth hormone therapy in chronic renal failure and post transplant. Pediatr Nephrol 1997;11:752-754.

-66 Rosenfeld RG, Bakker B: Compliance and persistence in pediatric and adult patients receiving growth hormone therapy. Endocr Pract 2008;14:143-154.

67 Gács G, Hosszu E: The effect of socio-economic conditions on the time of diagnosis and compliance during treatment in growth hormone deficiency. Acta Paediatr Hung 1991;31:215-221

68 Kirk J, Akhtar S, Zia R PM: Home delivery with hospital tracking improves $\mathrm{GH}$ compliance. Horm Res 2002;58(suppl 2):P2-P382.

69 Leiberman E, Pilpel D, Carel CA, Levi E, Zadik Z: Coping and satisfaction with growth hormone treatment among short-stature children. Horm Res 1993;40:128-135.

70 Stanhope R, Albanese A, Moyle L, Hamill G: Optimum method for administration of biosynthetic human growth hormone: a randomised crossover trial of an Auto Injector and a pen injection system. Arch Dis Child 1992;67:994-997.

71 Müller J, Skakkebaek NE, Jacobsen BB, Keller E, Heinrich U, Hartmann K, et al: Norditropin SimpleXx: a liquid human growth hormone formulation, a pen system and an autoinsertion device. Horm Res 1999;51(suppl 3):109-112.

72 Jørgensen JT: Improvement of patient convenience in treatment with growth hormone. J Pediatr Endocrinol 1994; 7:175-180.

73 Dumas H, Panayiotopoulos P, Parker D, Pongpairochana V: Understanding and meeting the needs of those using growth hormone injection devices. BMC Endocr Disord 2006; 6:5.

74 Norgren S: Adherence remains a challenge for patients receiving growth hormone therapy. Pediatr Endocrinol Rev 2009;6(suppl 4):545548

75 López Siguero JP, Martínez Aedo MJ, López Moreno MD, Martínez Valverde A: Treatment with growth hormone: what do children know and how do they accept it? Horm Res 1995;44(suppl 3):18-25.

76 Johannsson G: Long-acting growth hormone for replacement therapy. J Clin Endocrinol Metab 2011;96:1668-1670.

Fisher/Acerini 